Article

\title{
Evaluation of the Coupling of a Hybrid Power Plant with a Water Generation System
}

\author{
Amanda del Moral and Fontina Petrakopoulou * \\ Department of Thermal and Fluid Engineering, University Carlos III of Madrid, Avda. de la Universidad 30, \\ 28911 Leganés (Madrid), Spain; amandasabroso@gmail.com \\ * Correspondence: fpetrako@ing.uc3m.es
}

Received: 20 September 2019; Accepted: 11 November 2019; Published: 20 November 2019

\begin{abstract}
This paper presents the design and analysis of an energy/water system that combines a 20 MW hybrid concentrated solar/biomass power plant with an advanced wastewater treatment facility. Designed to be installed in one of the most demanding areas of the Iberian Peninsula, the Spanish region of Andalusia, this plant seeks to provide the area with potable water and electricity. The solar block works with a mixture of molten salts, while the biomass backup system of the power plant uses olive pomace. The implementation of a direct potable reuse facility further enhances the sustainability of the project. Urban sewage from the region is collected and passed through a series of purification procedures in order to generate potable water ready to be directly blended into the water distribution system. A sensitivity analysis is conducted to determine the feasibility of the co-generation of electricity and water in the area. With a capacity factor of $85 \%$ and an annual operation of 7,446 hours, the hybrid solar/biomass power plant generates $148.92 \mathrm{GWh}$. Exergetic analyses have been realized for two extreme cases: exclusive use of the solar block and exclusive use of the biomass system. An overall plant exergetic efficiency of $15 \%$ is found when the solar block is used and an efficiency of $34 \%$ is calculated when the biomass support system is used. Following an economic analysis, a total investment of $211,526,000 €$ is required for the full implementation of the system with a resulting levelized cost of energy of $0.25 € / \mathrm{kWh}$. We find that the selling price of the generated potable water which makes the plant operation economically viable is found to be $14.61 € / \mathrm{m}^{3}$. At present, this price seems relatively high in view of current conditions; yet it is expected to become more realistic under future heightened water scarcity conditions, especially in arid regions.
\end{abstract}

Keywords: hybrid solar power plant; solar tower; biomass combustion; exergy analysis; economic analysis; potable water reuse

\section{Introduction}

Global economic progress, population increase, and the technological development of emerging countries lead to a constant growth in demand of water and energy [1]. It is undeniably true that water is a vital resource, fundamental to life and health. Access to water and sanitation requires the consumption of energy. The generation of energy, on the other hand, requires large amounts of water. In this way, water and energy are closely interrelated [2]. The future of global sustainability depends on the achievement of an optimized use of both resources that will provide a viable solution for future generations.

In recent years, the use of Renewable Energy Sources (RES) within the energy sector has been increasing, currently accounting for $13.7 \%$ of the global energy supply. At present, however, about $80 \%$ of all primary energy in the world is still derived from fossil fuels, namely $31.7 \%$ from oil, $28.1 \%$ from coal and $21.6 \%$ from natural gas [3]. Although great amounts of energy can be obtained from fossil fuels, their use has a high environmental impact. Continuous release of pollutants to the atmosphere 
leads to considerable environmental and health problems [4]. In addition, climate change linked to fossil fuel combustion presents an important long-term impact on the availability and quality of water worldwide [5].

Today, Hybrid Power Plants (HPP) play an important role in the future of sustainable energy generation. HPPs combine two or more energy resources, make use of existing infrastructure and aggregate new components to combine the advantages of the combined resources. They can thus lead to secure and continuous energy production, savings in combustibles and reduction of harmful emissions. It is common that at least one of the energy sources is renewable, though the priority is to choose the most efficient and reliable mix of energy technologies to satisfy the users' needs. The combination of conventional thermal power plants with RES helps to transition away from fossil fuel use [6].

RES provide an alternative to fossil fuels and can help to mitigate greenhouse gas emissions and global warming [7]. Solar energy can be captured by means of two fundamental methods, photoreaction and heat, that can be combined in several ways to produce heat and electricity. Within these processes, Concentrating Solar Power (CSP) allows the collection of solar energy at relatively high working temperatures, resulting in better conversion efficiencies of heat into electricity [8]. CSP systems are based on the concentration of direct solar irradiance onto a specific area through mirrors or lenses that is then used to heat up the working fluid of the process. The harnessed energy by the working fluid is then directly or indirectly used to drive a steam turbine coupled to an electric generator [9]. Technologies used include parabolic troughs, Fresnel reflectors, parabolic dishes and solar towers [10]. Three major solar power plants can be found in the surrounding areas of Seville: PS10 and PS20, with water as working fluid, and Gemasolar with molten salts technology and 15 hours of storage facilities. PS10 is a plant with $11 \mathrm{MW}$ of installed capacity and it consists of a solar field with 624 heliostats and a receiver tower of a height of 115 meters. PS20 and Gemasolar have an installed capacity of $20 \mathrm{MW}$ and 19.9 MW, respectively [11].

There have been several studies on the coupling of CSPs with other conventional fuels or renewable energies in recent years in literature. A review of hybrid plant configurations involving CSP and fossil fuel was realized in 2012 by Sheu et al [12]. In that paper, solar-fossil fuel hybrids are classified by the authors into three general categories: combined cycles, solarized gas turbines and solar reforming. Examples of these categories include the Gemasolar solar plant in Spain [10] and the SEGS II-IX in California, both using natural gas backup for evaporation and superheating [13].

The integration of CSP with geothermal energy is another promising hybridization alternative. CSP-geothermal hybrids take advantage of the thermal energy beneath the surface of the Earth to produce electricity. The exact way to use this energy depends on the kind of the geothermal resource and the temperatures reached [14]. Located in Nevada (USA), Stillwater consists of a triple hybrid power plant that integrates 33.1 MW of geothermal energy with 26.4 MW of photovoltaic power and $2 \mathrm{MW}$ of solar thermal capacity [15]. Furthermore, CSP-wind hybrids have been increasing their potential as an excellent renewable alternative for energy generation. Wind is available all over the world, and its low cost makes it attractive for hybridization processes [16]. However, the combination of wind energy with CSP is a field that has not being widely explored. This is primarily because the two renewable energies do not have great synergy in terms of successful share of infrastructure, contrary to other thermal energy sources [17].

Biomass also constitutes an attractive choice for the hybridization of CSP plants for continuous operation. Early proposals to combine CSP with waste materials using dish technology were briefly discussed in the 1980s but were not further considered for financial and technical reasons [18]. After approximately two decades the first operating commercial CSP-biomass plant, Termosolar Borges, was constructed in Lleida, Spain [6]. The plant has a capacity of $22.5 \mathrm{MW}$ and an annual electrical production of 98,000 MWh. It has been in operation since December 2012, using the mature parabolic trough technology with thermal oil as the working fluid [19]. Despite the fact that biomass does not occupy a very significant place in the current renewable energy use in the country, especially 
if compared to wind and solar technologies, in 2011 biomass was used to generate $11.25 \%$ of the electricity in Spain [20]. Andalusia currently has a significant biomass wealth, largely originated from the olive cultivation and its surrounding industry. Olive oil industries produce $77.25 \%$ of the residual biomass, making the olive sector the greatest producer of biomass within this region [21]. At present, there are 18 electric biomass and cogeneration power plants in Andalusia with a total installed power of 257.48 MW and 19 biogas plants with $30.75 \mathrm{MW}$ of power [22].

Several studies have analyzed the hybridization of parabolic trough plants with biomass [23-25]. Fresnel technology has also been investigated for the hybridization with biomass and other waste materials [24]. A significant advantage of these systems is the relatively high steam temperatures of up to $500^{\circ} \mathrm{C}$, which lead to higher conversion efficiencies. Nevertheless, no reference hybrid plants exist yet [25]. From the great variety of possible CSP-biomass hybridizations, solar tower and gasification have been reported to result in energy efficiencies of up to 33.2\% [26]. However, no project has dealt with the use of these technologies within the same facility [27].

Increasing water demand, limited freshwater, and climate change make water reuse a necessary step to meet global water demand. Some recent studies on the combination of hybrid plants with desalination for water generation can be found in the literature [28-30]. In this work, the energy/water system is supported by a wastewater purification facility. Today, plans of wastewater management include not only the generation of sufficiently purified water to be returned to a natural water source, but also the further reuse of used water in downstream processes [31]. For this purpose, sewage undergoes different physical, chemical and biological processes to reduce pollutants according to its downstream use [32]. In the case of potable water, it is obtained by means of two fundamental procedures: Indirect (IPR) and Direct Potable Reuse (DPR) [33]. The major difference between these wastewater treatment plants (WWTP) is the use of an environmental buffer between the spillage and the collection point of water.

The Goreangab Reclamation Plant has been a pioneer in DPR [34]. The plant started operation in 1968 with the aim of averting water shortages in Windhoek, Namibia. However, throughout the years, its treatment train has been continuously evaluated and upgraded to find the most effective processes and barriers for safe drinking water [35]. More recent DPR projects include the Wichita Falls River Road and the Big Spring (2013) facilities, both located in Texas, USA [36]. The first began its operation in July 2014 as an emergency potable water supply in response to severe drought conditions. The latter has been operating since 2013, blending treated and raw water resources before their further processing and distribution within the region.

In Spain, renewable energy and water reclamation systems are increasing, not only due to technological developments but also due to the increase of political commitment and awareness of the population [37]. The Spanish energetic scenario has changed during the past years, evolving from a centralized generation system based on fossil energies, towards a more efficient system of distributed generation [38]. In terms of installed solar capacity, Spain had 1,950 MW shared among 43 facilities by the end of 2012. Most of the plants use parabolic troughs, while three plants use central receivers and one Fresnel reflectors [37]. However, the wider adoption of RES suffered a significant slowdown during several years, mostly as a consequence of the recent economic crisis and the technological immaturity and over-capacity of the system. It was only in 2018 that the renewable sector started to recover, driven by energy bids and costs reduction, which resulted in a 70\% growth, with respect to 2007 [39]. The published Plan of Renewable Energy predicts that CSP plants will be generating 3\% of the Spanish electricity by 2020 [40].

Furthermore, the lack of rain in Spain, along with the rising temperatures, has resulted in a reduction on the availability of freshwater reservoirs, leading to emergency levels especially in several areas of the Iberian Peninsula [41]. During the last decade, several aspects have enhanced the development of water reuse at the national level, primarily regulated by the Royal Decree 1620/2007 of December 7th [42]. This Decree establishes the basic quality requirements of water for different non-potable applications in Spain. Since 2008, the country has been working on the improvement of 
the treatment trains to meet current standards. Nowadays, the most common treatment trains in any reuse application in Spain include specific disinfection methods such as physical-chemical treatments followed by sand filtration together with ultraviolet (UV) radiation or chlorination [43].

The potential combination of hybrid power plants with water recycling can constitute a unique and innovative alternative for emerging energy/water global problems; yet an important research gap exists in this field. This paper studies the design, thermodynamic and economic characteristics of a system coupling a hybrid solar/biomass plant (20 MW central receiver power plant with a biomass support system) with an advanced wastewater treatment facility. It must be mentioned that this study constitutes a simplified, steady-state analysis that does not consider the hourly dynamic behavior of the plant. The main objective is to reveal the potential of the continuity of energy supply, the economic viability and the contribution of renewable energy through a detailed simulation and analysis of the proposed plant. This project is designed to be installed in Fuentes de Andalucía, a town located $57 \mathrm{~km}$ away from the Spanish province of Seville, to evaluate the viability of this kind of plants in one of the most water and energy demanding areas of the Iberian Peninsula. The solar block consists of a heliostats field that concentrates the incoming radiation towards a fixed receiver located at the top of a solar tower. Molten salts passing through the central receiver work as the heat transfer fluid collecting the thermal energy used to generate electricity. The biomass block, which serves as a backup facility, uses olive pomace.

Section 2 of this work describes the specific methodology followed to analyze the viability of the plant proposed, while Section 3 includes the overall description of all subsystems comprising the CSP-biomass plant and water reclamation facility. Ultimately, Section 4 presents and discusses the results obtained with the aim to evaluate this kind of large-scale engineering projects.

\section{Methodology}

\subsection{Exergetic Analysis}

In contrast to energy, exergy can be destroyed or lost. An exergetic analysis is a helpful tool in the evaluation of energy conversion systems because it reveals the main sources of inefficiencies in a component or a process. Basic exergy definitions and other relevant aspects of this analysis are presented in [44].

The exergetic efficiency (\%) of a component or a process, $\varepsilon$, is defined as:

$$
\varepsilon=\frac{\dot{E}_{P}}{\dot{E}_{F}}
$$

The exergy of the product $\left(\dot{E}_{P}\right)$ is the desired outcome from the operation of the specific component or system. The exergy of the fuel $\left(\dot{E}_{F}\right)$ is the input required to generate the final product.

The exergy of solar power in the case of thermosolar plants is calculated applying the following equation [45]:

$$
\dot{E}_{S}=\dot{Q}_{S} \cdot \Psi_{S}=A_{R e f l} \cdot D N I \cdot \Psi_{S}
$$

where, $\dot{Q}_{S}$ is the heat flow rate $(\mathrm{W})$ that reaches the solar field, defined by the DNI $\left(\frac{\mathrm{W}}{\mathrm{m}^{2}}\right)$ and the heliostats reflective surface $A_{\text {Refl }}\left(m^{2}\right) . \Psi_{S}$ is the ratio between exergy and energy calculated as:

$$
\Psi_{S}=\left[1-\frac{4}{3}\left(\frac{T_{a}}{T_{S}}\right)+\frac{1}{3}\left(\frac{T_{a}}{T_{S}}\right)^{4}\right]
$$

where, $T_{a}$ is the ambient temperature and $T_{s}$ is the apparent black body temperature of the sun $(5600 \mathrm{~K})$. 


\subsection{Economic Analysis}

The economic analysis is realized using the method of the Total Revenue Requirement (TRR). First, the Fixed Capital Investment (FCI) of the plant is estimated and specific assumptions for the analyzed scenario are taken from $[11,46]$. To calculate the cost of a component based on a reference component of a different capacity, we use Equation 4. The calculation is based on a scaling exponent, $\alpha$, which remains constant within a given size range and takes values lower than unity [44].

$$
C_{P E, 1}=C_{P E, 2} \cdot\left(\frac{X_{1}}{X_{2}}\right)^{\alpha}
$$

The calculated costs are scaled to the reference year (2018) by means of the chemical engineering plant cost index (CEPCI), as published in the Chemical Engineering Magazine [46].

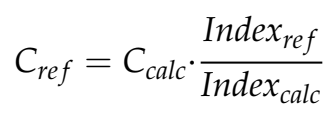

The Levelized Cost of Electricity (LCOE) compares unitary costs over the economic life of energy systems. The LCOE is calculated in $\frac{\epsilon}{k W h}$ using Equation (6) and includes the TRR over the 20 years of the plant life and the total energy generation $\left(E_{g e n}\right)$. The TRR contains the required initial investment $\left(C_{\text {capital }}\right)$, the cost of fuel $\left(C_{f u e l}\right)$ and the operation and maintenance costs $\left(C_{O \& M}\right)$ in current euros. For its part, the total energy generated is calculated taking into account the capacity factor of the plant $\left(C_{f}\right)$, the working hours $(t)$, and the total amount of power generated over this period of time $\left(P_{\text {gen }}\right)$ [47].

$$
L C O E=\frac{T R R}{E_{g e n}}=\frac{C_{\text {capital }}+C_{O \& M}+C_{f u e l}}{C_{f} \cdot t \cdot P_{g e n}}
$$

Currently, no reliable approaches for the calculation of the costs of wastewater treatment systems have been published in the literature. A mathematical model based on the Levenberg-Marquardt algorithm and the SigmaPlot Version 12.0 software has been used here to synthesize cost results for general applicability [48]. In this way, we can establish a relationship between the treatment technologies and the costs within the water reclamation facility. To fit the available cost data adequately over several orders of scale of systems, a logarithmic variant of Williams' law has been applied [49].

\subsection{Sensitivity Analysis}

For the purpose of this work, we realize a sensitivity analysis to determine the level of feasibility of the proposed project. Equation (7) is used as an indicator of the maximum required price of water that will make the proposed advanced plant economically viable.

$$
\text { Price }_{w} \geq \frac{\operatorname{Price}_{e}\left(\frac{\epsilon}{k W h}\right) \cdot \text { Energy }_{\text {net }}(k W h)}{\operatorname{Mass}_{w}\left(m^{3}\right)}
$$

To carry out this analysis, several parameters are required, including the net amount of energy generated and the part of electricity required to purify sewage. The energy requirements for each advanced treatment by volume of water is calculated by means of equations published [50]. The aim of the plant is to supply potable water to the same amount of people it provides electricity to. The net energy is calculated then by the difference between the total amount of energy generated within the HPP and the total amount of energy required to treat the wastewater. The price of electricity assumed for this analysis is that of Spain with an average current value of $0.13 € / \mathrm{kWh}$ [51]. Thus, the final price of water depends on the treated water capacity of the reclamation plant and the resulting energy required to carry out the purification process. 


\section{Simulations}

\subsection{CSP-Biomass Power Plant}

The CSP-biomass HPP is modelled using the commercial software EBSILON®Professional. This tool is designed for power plant and thermodynamic process analysis. The software allows access to a large set of component libraries and input variables to describe in detail the working characteristics of the modelled system.

The system simulation flow diagram is shown in Figure 1. The solar energy system includes the central receiver, the solar tower and the heliostats field. The solar field uses 110 ha and it is composed of 1458 mirrors made of high reflective glass. The heliostats have a rectangular design of $120 \mathrm{~m}^{2}$ and an average reflectivity of 0.9 that lead to a total reflective area of $174,960 \mathrm{~m}^{2}$ [11]. The solar plant requires specific meteorological data, such as the Direct Normal Irradiance (DNI) and the ambient temperature. These data are obtained from previous studies that report an average irradiance in Seville of $850 \mathrm{~W} / \mathrm{m}^{2}$ and an ambient temperature of $20^{\circ} \mathrm{C}$ [52].

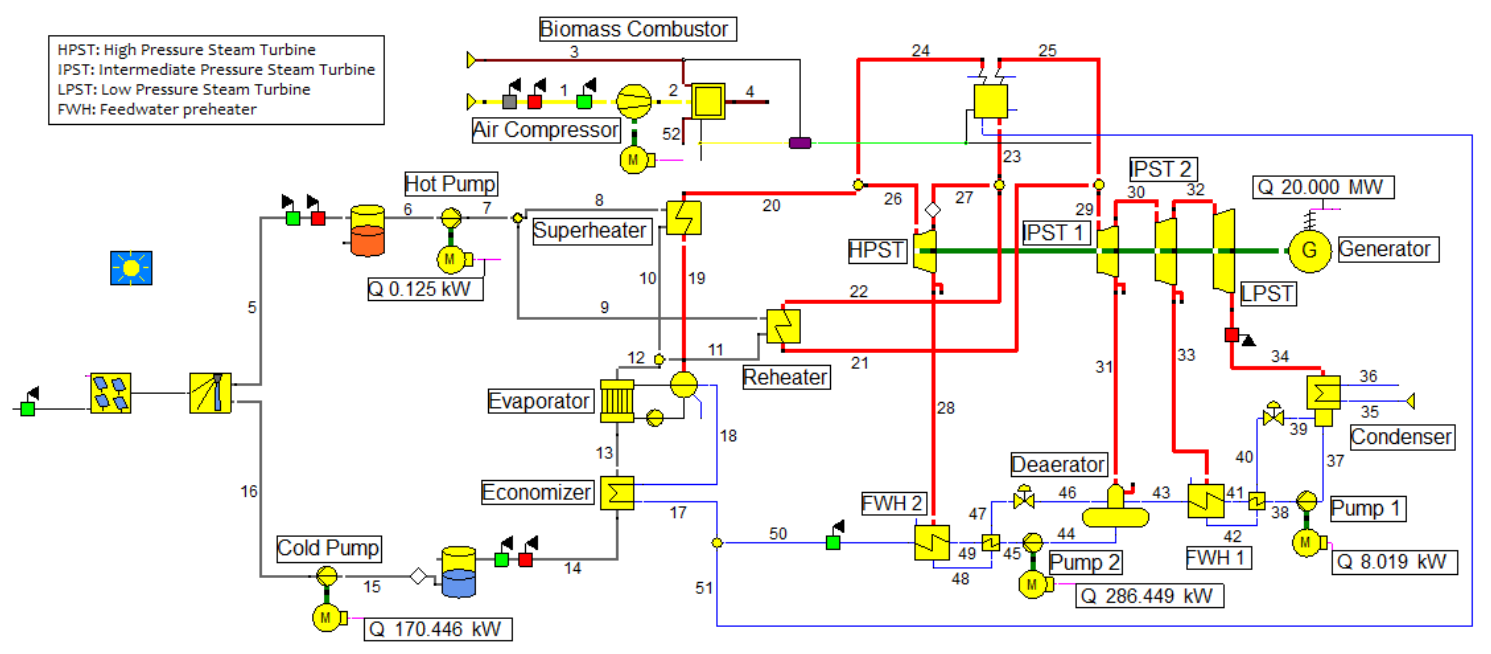

Figure 1. Diagram of the reference HPP.

The cylindrical receiver is located at an optical height of $127 \mathrm{~m}$ and has a thermal power of $100 \mathrm{MWth}$ at the design point. A mixture of $60 \%$ sodium nitrate $\left(\mathrm{NaNO}_{3}\right)$ and $40 \%$ potassium nitrate $\left(\mathrm{KNO}_{3}\right)$ molten salts is used as the working fluid to capture and transfer heat from the solar receiver [10]. The salts work as a high-temperature fluid and as a cooling fluid for the receiver. The inlet and outlet temperatures of the molten salts are 290 and $565{ }^{\circ} \mathrm{C}$, respectively. This results in a mean wall temperature of the receiver of $480^{\circ} \mathrm{C}$. The thermal storage system consists of two tanks of different temperatures from where the molten salts are pumped either towards the steam generator or the receiver. The thermal storage has a total capacity of $600 \mathrm{MWh}$, providing an autonomy of up to 4 hours.

Once heated, the molten salts are led from the hot storage tank to the power block. There, it flows through different heat exchangers to generate steam and passes through the turbine of the plant. The steam turbine turns thermal energy into mechanical energy driving a generator that converts mechanical energy into electricity. The steam leaving the turbine goes through a condenser to be converted to its initial liquid state and complete the cycle.

The supporting biomass system consists of a biomass boiler fired with olive pomace, which enables plant operation during periods of solar absence or low levels of thermal energy in the storage tanks. In this work, it is assumed that olive pomace is instantly available, already dry with about $10 \%$ moisture and is ready to be introduced into the boiler at any point in time. Selected operating parameters for the power block can be seen in Table 1 . These values are based on existing reference plants and technical reports concerning similar hybridization projects [51-53]. 
Table 1. Power block operational parameters.

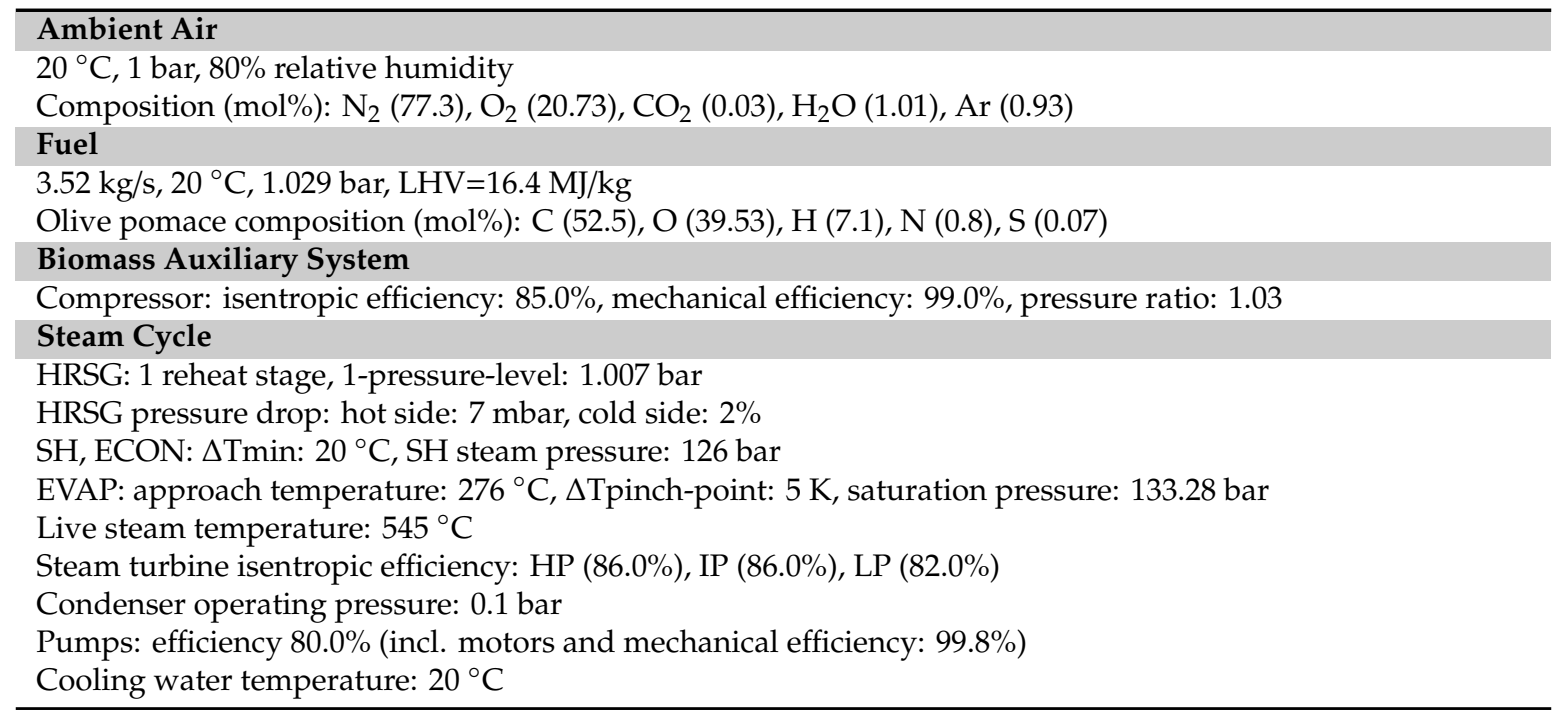

\subsection{Wastewater Treatment Plant}

Part of the electricity generated in the HPP is used to run the proposed WWTP that aims to provide the region with drinking water. The wastewater treatment train is shown in Figure 2. Wastewater is collected and guided towards the treatment plant, where it undergoes a series of physical, biological and chemical procedures during the first stage of the purification process. First, primary settling takes place eliminating any suspended solids using gravity, enhanced by the action of coagulants and flocculants [32]. Then, a membrane bioreactor removes organic and nitrogen constituents of wastewater [50]. On the completion of these treatments, the water is put in waste stabilization ponds for about 3-4 days, where pathogenic microorganisms and certain nutrients are removed by means of natural procedures.
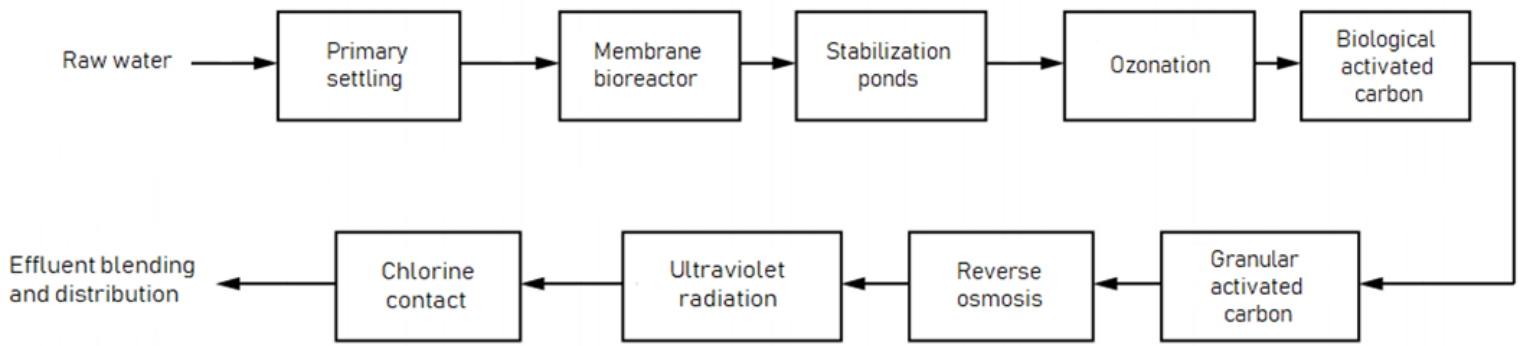

Figure 2. Wastewater treatment train.

After these conventional procedures, more advanced operations are required to fulfill the established water quality requirements suitable for human consumption. These include ozone disinfection for bacteria and viruses inactivation, as well as algae control [53]. In the next step, Biological and Granular Activated Carbon (BAC \& GAC) polish water by means of several filters that remove as much organic load as possible [54]. Then, reverse osmosis (RO) reduces disinfection byproducts, salt concentration and removal of dissolved organic carbon [55]. Ultraviolet radiation constitutes an effective key stage against multiple pathogens and other bacterial illnesses. Chlorination dosage is the final disinfection barrier for the ultimate inactivation of pathogens [56]. Finally, the purified water is returned to the potable supply system without the need for an environmental buffer. It is assumed that the plant is operated and closely monitored to avoid failures within the different disinfection stages. In the event of an error, the water is rejected or recirculated to the beginning of the treatment train. 


\section{Results}

\subsection{Exergetic Analysis}

Having assumed $850 \mathrm{~W} / \mathrm{m}^{2}$ of DNI at Fuentes de Andalucía and an ambient temperature of $20^{\circ} \mathrm{C}$, the solar exergy received at the solar field is $138 \mathrm{MW}$. For the system under consideration, the exergetic efficiencies of the plant components are shown in Table 2. Specific properties for each stream of the power plant simulation can be found in Tables A1 and A2 of the appendix of the paper. According to the data obtained, it is noticed that the exergetic efficiencies of the majority of the power plant components generally exceed $80 \%$.

Table 2. Exergetic efficiencies of power plant components.

\begin{tabular}{|c|c|c|c|c|c|}
\hline \multirow[b]{2}{*}{ Component } & \multicolumn{2}{|c|}{ Stream Balances } & \multicolumn{2}{|c|}{ Stream Values (kW) } & \multirow[b]{2}{*}{$\varepsilon(\%)$} \\
\hline & $E_{P}$ & $E_{F}$ & $E_{P}$ & $E_{F}$ & \\
\hline $\begin{array}{c}\text { Air } \\
\text { Compressor }\end{array}$ & $\dot{E}_{2}-\dot{E}_{1}$ & $\dot{W}$ & 114.98 & 139.58 & 82.38 \\
\hline $\begin{array}{l}\text { Biomass } \\
\text { Combustor }\end{array}$ & $\begin{array}{c}\dot{E}_{24}-\dot{E}_{51}- \\
\dot{E}_{25}-\dot{E}_{23}\end{array}$ & $\dot{E}_{\text {Biomass }}$ & $26,979.72$ & $63,536.00$ & 42.46 \\
\hline Pump 1 & $\dot{E}_{38}-\dot{E}_{37}$ & $\dot{W}$ & 6.41 & 8.02 & 79.89 \\
\hline Pump 2 & $\dot{E}_{45}-\dot{E}_{44}$ & $\dot{W}$ & 240.87 & 286.45 & 84.09 \\
\hline HPST & $\dot{W}$ & $\dot{E}_{26}-\dot{E}_{28}-\dot{E}_{27}$ & $5,200.00$ & $5,542.65$ & 93.82 \\
\hline IPST 1 & $\dot{W}$ & $\dot{E}_{29}-\dot{E}_{31}-\dot{E}_{30}$ & $7,600.00$ & 8,199.54 & 92.69 \\
\hline IPST 2 & $\dot{W}$ & $\dot{E}_{30}-\dot{E}_{33}-\dot{E}_{32}$ & $5,600.00$ & $6,384.02$ & 87.72 \\
\hline LPST & $\dot{W}$ & $\dot{E}_{32}-\dot{E}_{34}$ & $2,100.00$ & $2,605.15$ & 80.61 \\
\hline FWH 1 & $\dot{E}_{43}-\dot{E}_{38}$ & $\dot{E}_{33}-\dot{E}_{40}$ & 289.91 & 347.95 & 83.32 \\
\hline FWH 2 & $\dot{E}_{50}-\dot{E}_{45}$ & $\dot{E}_{28}-\dot{E}_{47}$ & 115.39 & 151.13 & 76.35 \\
\hline Economizer & $\dot{E}_{18}-\dot{E}_{17}$ & $\dot{E}_{13}-\dot{E}_{14}$ & $3,421.20$ & $4,024.58$ & 85.01 \\
\hline Evaporator & $\dot{E}_{19}-\dot{E}_{18}$ & $\dot{E}_{12}-\dot{E}_{13}$ & $11,414.47$ & $12,880.55$ & 88.62 \\
\hline Superheater & $\dot{E}_{20}-\dot{E}_{19}$ & $\dot{E}_{8}-\dot{E}_{10}$ & $7,080.78$ & $7,621.87$ & 92.90 \\
\hline Reheater & $\dot{E}_{21}-\dot{E}_{22}$ & $\dot{E}_{9}-\dot{E}_{11}$ & 3,787.17 & $4,105.00$ & 92.26 \\
\hline Cold Pump & $\dot{E}_{16}-\dot{E}_{15}$ & $\dot{W}$ & 163.76 & 170.45 & 96.07 \\
\hline Hot Pump & $\dot{E}_{7}-\dot{E}_{6}$ & $\dot{W}$ & 0.1195 & 0.125 & 95.62 \\
\hline
\end{tabular}

The highest exergy destruction is calculated in the biomass combustor, mainly due to the chemical reaction taking place there. Part of this exergy destruction can be avoided by preheating the reactants and by reducing the excess air. Another significant source of irreversibilities is the heat transfer between streams with high temperature differences. Such is the case of feedwater preheaters which tend to have lower exergy efficiencies, as a result of the high temperature difference between the steam turbine extractions and the water streams. Although the condenser is characterized by a relatively high exergy destruction, it is required to increase the total performance of the remaining plant components and allow lower pressures at the exit of the turbine.

The overall solar efficiency of the power plant reaches a value of $15 \%$, a value slightly lower when compared to other concentration technologies [57]. However, this value is enhanced by the use of thermal storage which provides autonomy to the plant and guarantees robust operation. Although a large part of the irreversibilities cannot be avoided, as in the case of the combustion process, actions can be incorporated to mitigate these effects. Further improvements can be achieved with the development of solar technology. In the coming years, advances within components and working fluids are expected to increase the total efficiency of power plants. 


\subsection{Economic Analysis}

The total net capital investment of the proposed project including the hybrid solar/biomass and wastewater plants reaches the $211,526,743.00 €$. Adjusting the calculations require the use of scaling exponents ranging from 0.8 to 0.9 depending on the component. The estimated costs are shown in Table 3. Required investment for other projects of the same magnitude, such as the Gemasolar power plant at the same location and with similar operational characteristics, are of a comparable scale [58]. The final investment calculated here is somewhat higher as a consequence of the hybridization of the plant and the implementation of the water reuse technologies [50].

Table 3. Purchased equipment costs.

\begin{tabular}{|c|c|}
\hline Component & Investment $(€)$ \\
\hline \multicolumn{2}{|c|}{ Solar Energy Capture System } \\
\hline Mirrors & $1,995,924.00$ \\
\hline Metal Structure & $13,971,469.00$ \\
\hline Solar Tracker & $9,702,409.00$ \\
\hline Land Movement & $1,746,434.00$ \\
\hline Foundations & $1,164,289.00$ \\
\hline Assembly & $3,326,540.00$ \\
\hline Assembly Unit & $831,635.00$ \\
\hline \multicolumn{2}{|c|}{ Solar Energy Conversion System } \\
\hline Working Fluid (Molten Salts) & 82.00 \\
\hline Solar Tower Receiver & $21,361,270.00$ \\
\hline Mechanical System & $2,967,182.00$ \\
\hline Fire Protection & $513,355.00$ \\
\hline Inertisation System & $285,197.00$ \\
\hline Solar Tower Construction & $3,497,735.00$ \\
\hline \multicolumn{2}{|c|}{ Thermal Energy Storage System } \\
\hline Transfer System: Tanks \& Pipes & $2,813,946.00$ \\
\hline Initial Filling System & $268,085.00$ \\
\hline Construction & $671,164.00$ \\
\hline \multicolumn{2}{|c|}{ Power Block } \\
\hline Air Compressor & $970,173.00$ \\
\hline Biomass Combustor & $1,196,008.00$ \\
\hline Economizer & $414,050.00$ \\
\hline Evaporator & $2,947,812.00$ \\
\hline Superheater & $482,861.00$ \\
\hline Reheater & $1,021,964.00$ \\
\hline Deaerator & $14,728.00$ \\
\hline Condenser & $487,326.00$ \\
\hline Pump 1 & $8,890.00$ \\
\hline Pump 2 & $60,934.00$ \\
\hline HSPT & $1,365,160.00$ \\
\hline IPST & $5,237,489.00$ \\
\hline LPST & $1,102,629.00$ \\
\hline FWH 1 & $650,061.00$ \\
\hline FWH 2 & $26,197.00$ \\
\hline \multicolumn{2}{|c|}{ Water Reuse Technologies } \\
\hline Membrane Bioreactor & $10,446,739.00$ \\
\hline Ozonization & $78,849.00$ \\
\hline BAC \& GAC & $1,810,718.00$ \\
\hline Reverse Osmosis (RO) & $1,931,911.00$ \\
\hline Ultraviolet Radiation (UV) & $112,469.00$ \\
\hline Chlorination & $20,731.00$ \\
\hline
\end{tabular}

The solar plant is responsible for an important part of the total investment of the power plant. This is mainly due to the heliostat field and the solar tracking system of the mirrors. To ensure good 
tracing of the solar position and adequate rigidity of the components, a solar tracker and a metal structure are needed for each heliostat. Conditioning tasks to accommodate the plant, as well as required foundations for its proper assembly are also included in the cost calculations.

Another subsystem with great impact on the final investment of the power plant is the system converting the solar radiation into thermal energy. The solar tower presents significant particularities when compared to other technologies. The solar receiver constitutes an essential element of the system and it must be placed at a considerable height from the ground. This leads to higher investment costs on both materials and construction, when compared to other solar technologies. Furthermore, the pumping of the molten salts to reach the height of the receiver requires powerful equipment within the salts mechanical system.

Despite the great number of additional operational hours achieved with the thermal storage, its incorporation into the plant causes a significant increase in the investment cost. Thermal energy is stored within two insolated storage tanks with different temperatures. Vertical pumps are also required for each tank to drive the fluid towards the fixed receiver and steam generator. These costs are included in the cost calculations of the mechanical system of the solar energy conversion system.

To calculate the required investment for the wastewater treatment train, the equations presented in the methodology are applied. The calculated costs for the facility are significant, due to the application of expensive wastewater treatment methods with relatively new purification techniques.

The LCOE shows the relation between the TRR and the total amount of generated electricity over the assumed 20 years of the plant economic life. Using Equation 6, a LCOE of $0.25 € / \mathrm{kWh}$ is calculated for the plant with a TRR of $738,740,000 €$ and a capacity factor of $85 \%$. This cost is found to be comparable with reported levelized cost of CSP technologies with a thermal storage of up to 4 hours $(0.22 € / \mathrm{kWh})[59]$. The slightly higher calculated LCOE in this work is associated with the additional use of biomass. It should finally be mentioned that the calculatedd LCOE does not include the gain from selling the water generated in the water reclamation plant, which strongly depends on regional and water-availability issues.

\subsection{Sensitivity Analysis}

The final acceptable price of water that constitutes out plant economically viable depends on the treated water capacity of the reclamation plant and the resulting energy required to carry out the whole purification process.

We seek to supply with potable water the same amount of people we provide electricity to, i.e., 27,500 homes. At present, the average daily water consumption in Spain is 132 liters/inhabitant/day. In the view of the above, a total treated water capacity of $3,630 \mathrm{~m}^{3} /$ day is assumed at the reclamation plant. In accordance to the aforementioned specific treatment train and the total water capacity, a final value of $1.84 \mathrm{MWh} /$ day is required. Another significant data point for the correct calculation of this analysis is the price of electricity. Here, we assume that of Spain, with a value of $0.13 € / \mathrm{kWh}$. If part of the generated electricity in the HPP is used to run the water reclamation plant, the selling price of drinking water is finally found to be $14.61 € / \mathrm{m}^{3}$.

To be regarded as a viable proposal under current conditions, either the necessary energy for water production or the price of electricity should be reduced, since the actual price of water in Spain is $1.66 € / \mathrm{m}^{3}$ [60]. Despite this, future water scarcity and climate change are expected to considerably increase the value of water, especially in arid areas with low reserves of water resources. Consequently, although this calculated price seems high today, it might become more realistic in the future.

\section{Conclusions}

The management of water and energy resources will face new challenges in the future due to increasing demand, the depletion of traditional energy sources and their environmental consequences, and increasing water scarcity. Within this context of great pressure on vital resources, climate change 
adds an additional level of complexity. The introduction of renewable solutions is thus essential for the achievement of short and mid-term sustainable objectives.

This work presented the simulation and analysis of a $20 \mathrm{MW}$ hybrid solar/biomass power plant combined with an advanced wastewater facility for a region in the province of Seville, Spain. The plant used molten salts as the working fluid and included two thermal storage tanks of a total capacity of $600 \mathrm{MWh}$ for operational autonomy of up to 4 hours. The biomass combustor was used as an auxiliary system, in the event of limited solar radiation or inadequate thermal energy in the storage tanks. The water treatment plant consisted of a direct potable reuse system with the objective of treating urban sewage and producing clean water for the selected region. The specific treatment train consisted of physical, biological and chemical procedures including membrane bioreactors, ozonization, biological and granular activated carbon, reverse osmosis, ultraviolet radiation and chlorination.

We found that the biomass combustor had the highest exergy destruction among all plant components due to the chemical reaction taking place there. Some heat exchangers, such as the feedwater preheaters, also display relatively low exergetic efficiencies due to the mixing of streams with great temperature differences. The full-load global exergetic efficiency of the power plant is found to be $15 \%$ when the solar part is used and $34 \%$ when the biomass support system is required. The net capital investment required for the construction and implementation of the plant was found to be $211,526,000 €$. This cost included both the hybrid power plant with thermal storage and the required advanced treatment technologies used to supply the region with potable water. The levelized cost of electricity of the combined plant was found to be $0.25 € / \mathrm{kWh}$, a value somewhat higher than existing solar tower power plants. Lastly, a sensitivity analysis of the water reclamation plant was conducted in order to evaluate the feasibility and viability of the project. The required selling price of the generated potable water was found to be $14.61 € / \mathrm{m}^{3}$. Accounting for present conditions, this cost is considered relatively high. However, foreseen future water limitations are expected to drive water prices up, especially in arid regions with intense lack of water resources. In essence, the combination of renewable energy plants with water generation processes will provide a valuable and profitable alternative for local communities to create environmentally safe facilities with continuous and stable power supply and the additional sustainable management of fresh water resources.

Author Contributions: Conceptualization, F.P.; investigation, A.d.M.; writing, A.d.M. and F.P.

Funding: Fontina Petrakopoulou is funded by the Ramón y Cajal Programme of the Spanish Ministry of Science, Innovation and Universities (Grant no. RYC-2016-20971).

Conflicts of Interest: The authors declare no conflict of interest.

\section{Nomenclature}

BAC

CEPCI

CSP

DPR

DNI

FCI

GAC

HPP

IPR

LCOE

RES

RO

TRR

UV

WWTP
Biological Activated Carbon

Chemical Engineering Plant Cost Index

Concentrated Solar Power

Direct Potable Reuse

Direct Normal Irradiance

Fixed Capital Investment

Granular Activated Carbon

Hybrid Power Plant

Indirect Potable Reuse

Levelized Cost of Electricity

Renewable Energy Sources

Reverse Osmosis

Total Revenue Requirement

Ultraviolet Radiation

Wastewater Treatment Plant 


\section{Appendix A}

Table A1. Solar plant stream results.

\begin{tabular}{|c|c|c|c|c|c|c|}
\hline $\begin{array}{l}\text { Stream } \\
\text { Number }\end{array}$ & $\begin{array}{c}\text { Mass Flow } \\
(\mathrm{kg} / \mathrm{s})\end{array}$ & $\begin{array}{c}\text { Temperature } \\
\left({ }^{\circ} \mathrm{C}\right)\end{array}$ & $\begin{array}{l}\text { Pressure } \\
\text { (bar) }\end{array}$ & $\begin{array}{l}\text { Enthalpy } \\
(\mathrm{kJ} / \mathrm{kg})\end{array}$ & $\begin{array}{c}\text { Entropy } \\
(\mathrm{kJ} / \mathrm{kg} \cdot \mathrm{K})\end{array}$ & Quality (x) \\
\hline 5 & 119.53 & 565.00 & 1.00 & 845.22 & 1.67 & 0 \\
\hline 6 & 119.53 & 565.00 & 1.00 & 845.22 & 1.67 & 0 \\
\hline 7 & 119.53 & 565.00 & 1.01 & 845.23 & 1.67 & 0 \\
\hline 8 & 59.77 & 565.00 & 1.01 & 845.23 & 1.67 & 0 \\
\hline 9 & 59.77 & 565.00 & 1.01 & 845.23 & 1.67 & 0 \\
\hline 10 & 59.77 & 428.29 & 1.01 & 635.67 & 1.39 & 0 \\
\hline 11 & 59.77 & 493.70 & 1.01 & 735.53 & 1.53 & 0 \\
\hline 12 & 119.53 & 461.07 & 1.01 & 685.60 & 1.46 & 0 \\
\hline 13 & 119.53 & 337.80 & 1.01 & 498.73 & 1.19 & 0 \\
\hline 14 & 119.53 & 290.00 & 1.01 & 426.96 & 1.06 & 0 \\
\hline 15 & 119.53 & 290.00 & 1.00 & 429.96 & 1.06 & 0 \\
\hline 16 & 119.53 & 290.92 & 21.99 & 428.34 & 1.06 & 0 \\
\hline 17 & 15.51 & 155.00 & 136.00 & 661.83 & 1.88 & 0 \\
\hline 18 & 15.51 & 276.37 & 133.28 & $1,214.91$ & 3.01 & 0 \\
\hline 19 & 15.51 & 332.80 & 133.28 & $2,655.01$ & 5.41 & 1 \\
\hline 20 & 15.51 & 545.00 & 126.00 & $3,462.47$ & 6.61 & 1 \\
\hline 21 & 15.38 & 545.00 & 33.25 & $3,555.23$ & 7.31 & 1 \\
\hline 22 & 15.38 & 360.01 & 35.00 & $3,128.95$ & 6.70 & 1 \\
\hline 26 & 15.51 & 545.00 & 126.00 & $3,462.47$ & 6.61 & 1 \\
\hline 27 & 15.38 & 360.01 & 35.00 & $3,128.95$ & 6.70 & 1 \\
\hline 28 & 0.13 & 360.01 & 35.00 & $3,128.95$ & 6.70 & 1 \\
\hline 29 & 15.38 & 360.01 & 30.00 & $3,555.23$ & 7.36 & 1 \\
\hline 30 & 13.63 & 298.07 & 4.50 & $3,061.88$ & 7.50 & 1 \\
\hline 31 & 1.75 & 298.07 & 4.50 & $3,061.88$ & 7.50 & 1 \\
\hline 32 & 12.97 & 81.04 & 0.40 & $2,646.38$ & 7.70 & 1 \\
\hline 33 & 0.66 & 81.04 & 0.40 & $2,646.38$ & 7.70 & 1 \\
\hline 34 & 12.97 & 45.81 & 0.10 & $2,477.29$ & 7.81 & 0.96 \\
\hline 35 & 341.13 & 20.00 & 1.01 & 84.01 & 0.30 & 0 \\
\hline 36 & 341.13 & 40.81 & 0.51 & 170.95 & 0.58 & 0 \\
\hline 37 & 13.63 & 45.81 & 0.10 & 191.81 & 0.65 & 0 \\
\hline 38 & 13.63 & 45.85 & 4.60 & 192.38 & 0.65 & 0 \\
\hline 39 & 0.66 & 45.81 & 0.10 & 204.55 & 0.69 & 0.01 \\
\hline 40 & 0.66 & 48.85 & 0.40 & 204.55 & 0.69 & 0 \\
\hline 41 & 13.63 & 47.16 & 4.55 & 197.86 & 0.67 & 0 \\
\hline 42 & 0.66 & 75.86 & 0.40 & 317.57 & 1.03 & 0 \\
\hline 43 & 13.63 & 74.16 & 4.50 & 310.77 & 1.01 & 0 \\
\hline 44 & 15.51 & 147.91 & 4.50 & 623.22 & 1.82 & 0 \\
\hline 45 & 15.51 & 150.14 & 136.10 & 641.07 & 1.83 & 0 \\
\hline 46 & 0.13 & 147.91 & 4.50 & 647.65 & 1.88 & 0.01 \\
\hline 47 & 0.13 & 153.14 & 35.00 & 647.65 & 1.87 & 0 \\
\hline 48 & 0.13 & 242.56 & 35.00 & $1,049.76$ & 2.73 & 0 \\
\hline 49 & 15.51 & 150.93 & 136.05 & 644.43 & 1.84 & 0 \\
\hline 50 & 15.51 & 155.00 & 136.00 & 661.83 & 1.88 & 0 \\
\hline
\end{tabular}


Table A2. Biomass stream results.

\begin{tabular}{|c|c|c|c|c|c|c|}
\hline $\begin{array}{l}\text { Stream } \\
\text { Number }\end{array}$ & $\begin{array}{c}\text { Mass Flow } \\
(\mathrm{kg} / \mathrm{s})\end{array}$ & $\begin{array}{c}\text { Temperature } \\
\left({ }^{\circ} \mathrm{C}\right)\end{array}$ & $\begin{array}{l}\text { Pressure } \\
\text { (bar) }\end{array}$ & $\begin{array}{l}\text { Enthalpy } \\
(\mathrm{kJ} / \mathrm{kg})\end{array}$ & $\begin{array}{c}\text { Entropy } \\
(\mathbf{k J} / \mathbf{k g} \cdot \mathrm{K})\end{array}$ & Quality (x) \\
\hline 1 & 46.74 & 20.00 & 1.00 & 20.30 & 6.92 & 1 \\
\hline 2 & 46.74 & 22.82 & 1.03 & 23.16 & 6.92 & 1 \\
\hline 3 & 3.52 & 20.00 & 1.03 & 21.35 & 0.43 & 0 \\
\hline 4 & 49.96 & 170.00 & 1.03 & 178.98 & 7.41 & 1 \\
\hline 23 & 14.65 & 390.00 & 35.00 & $3,199.80$ & 6.81 & 1 \\
\hline 24 & 14.77 & 580.00 & 126.00 & $3,552.96$ & 6.72 & 1 \\
\hline 25 & 14.65 & 580.00 & 30.00 & $3,637.42$ & 7.46 & 1 \\
\hline 28 & 0.12 & 390.01 & 35.00 & $3,199.80$ & 6.81 & 1 \\
\hline 30 & 13.02 & 326.05 & 4.50 & $3,119.54$ & 7.60 & 1 \\
\hline 31 & 1.63 & 326.05 & 4.50 & $3,119.54$ & 7.60 & 1 \\
\hline 32 & 12.40 & 100.18 & 0.40 & $2,684.03$ & 7.80 & 1 \\
\hline 33 & 0.62 & 100.18 & 0.40 & $2,684.03$ & 7.80 & 1 \\
\hline 34 & 12.40 & 45.81 & 0.10 & $2,511.16$ & 7.92 & 0.97 \\
\hline 35 & 330.89 & 20.00 & 1.01 & 84.01 & 0.30 & 0 \\
\hline 36 & 330.89 & 40.81 & 0.51 & 170.95 & 0.58 & 0 \\
\hline 37 & 13.02 & 45.81 & 0.10 & 191.81 & 0.65 & 0 \\
\hline 38 & 13.02 & 45.85 & 4.60 & 192.38 & 0.65 & 0 \\
\hline 39 & 0.62 & 45.81 & 0.10 & 204.55 & 0.69 & 0.01 \\
\hline 40 & 0.62 & 48.85 & 0.40 & 204.55 & 0.69 & 0 \\
\hline 41 & 13.02 & 47.14 & 4.55 & 197.78 & 0.67 & 0 \\
\hline 42 & 0.62 & 75.86 & 0.40 & 317.57 & 1.03 & 0 \\
\hline 43 & 13.02 & 74.16 & 4.50 & 310.77 & 1.01 & 0 \\
\hline 44 & 14.77 & 147.91 & 4.50 & 623.22 & 1.82 & 0 \\
\hline 45 & 14.77 & 150.14 & 136.10 & 641.07 & 1.83 & 0 \\
\hline 46 & 0.12 & 147.91 & 4.50 & 647.65 & 1.88 & 0.01 \\
\hline 47 & 0.12 & 153.14 & 35.00 & 647.65 & 1.87 & 0 \\
\hline 48 & 0.12 & 242.56 & 35.00 & $1,049.78$ & 2.73 & 0 \\
\hline 49 & 14.77 & 150.91 & 136.05 & 644.34 & 1.84 & 0 \\
\hline 51 & 14.77 & 155.00 & 136.05 & 661.83 & 1.88 & 0 \\
\hline 52 & 0.30 & 850.00 & 1.03 & 898.00 & 1.42 & 0 \\
\hline
\end{tabular}

\section{References}

1. WEF. The Water Food Energy Climate Nexus. In Water Security; Island Press: Washington, DC, USA, 2011; Volume 1.

2. Olsson, G. Water and Energy. Threats and Opportunities, 1st ed.; IWA Publishing: London, UK, 2012.

3. IEA Supply. Key World Energy Statistics 2017; OECD Pusblishing: Paris, France, 2017; pp. 6-25.

4. IEA. CO2 Emissions from Fuel Combustion 2017 Highlights; OECD Publishing: Paris, France, 2017.

5. Allen, L.; Cohen, M.J.; Elson, D.A.; Miller, B. Fossil Fuels and Water Quality. In The World's Water; Island Press: Washington, DC, USA, 2011; pp. 73-96.

6. Pramanik, S.; Ravikrishna, R.V. A review of concentrated solar power hybrid technologies. Appl. Therm. Eng. 2017, 127, 602-637. [CrossRef]

7. Panwar, N.L.; Kaushik, S.C.; Kothari, S. Role of renewable energy sources in environmental protection: A review. Renew. Sustain. Energy Rev. 2010, 15, 1513-1524. [CrossRef]

8. IEA. Solar thermal electricity. In Solar Energy Perspectives-Renewable Energy Technologies; IEA Publications: Paris, France, 2011; pp. 141-148.

9. Zhang, H.L.; Baeyens, J.; Eve, J.D.; Eres, G.C. Concentrated solar power plants: Review and design methodology. Renew. Sustain. Energy Rev. 2013, 22, 466-481. [CrossRef]

10. Baharoon, D.A.; Rahman, H.A.; Omar, W.Z.W.; Fadhl, S.O. Historical development of concentrating solar power technologies to generate clean electricity efficiently-A review. Renew. Sustain. Energy Rev. 2015, 41, 996-1027. [CrossRef] 
11. Ruiz, V.; Silva, M.; Lillo, I.; Moreno, S.; Domínguez, J.; Blanco, M.; Ramírez, L.; Sánchez, M.; García-Barberena, J.; García, P.; et al. Evaluación del Potencial de Energía Solar Termoeléctrica; IDAE: Madrid, Spain, 2011.

12. Sheu, E.J.; Mitsos, A.; Eter, A.A.; Mokheimer, E.M.A.; Habib, M.A.; Al-Qutub, A. A Review of Hybrid Solar-Fossil Fuel Power Generation Systems and Performance Metrics. J. Sol. Energy Eng. 2012, 134, 041006. [CrossRef]

13. Price, H.; Kearney, D. Reducing the Cost of Energy from Parabolic trough Solar Power Plants; ISEC: Coimbra, Portugal, 2003.

14. Zarrouk, S.J.; Moon, H. Efficiency of geothermal power plants: A worldwide review. Geothermics 2014, 51, 142-153. [CrossRef]

15. Dimarzio, G.; Angelini, L.; Price, W.; Chin, C.; Harris, S. The Stillwater Triple Hybrid Power Plant: Integrating Geothermal, Solar Photovoltaic and Solar Thermal Power Generation. In Proceedings of the World Geothermal Congress 2015, Melbourne, Australia, 19-25 April 2015; pp. 19-25.

16. IRENA. Renewable Energy Technologies: Cost Analysis Series-Wind Power; International Renewable Energy Agency: Abu Dhabi, UAE, 2012; p. 56.

17. Peterseim, J.H.; White, S.; Tadros, A.; Hellwig, U. Concentrating solar power hybrid plants-Enabling cost effective synergies. Renew. Energy 2014, 67, 178-185. [CrossRef]

18. McDonald, C.F. A hybrid solar closed-cycle gas turbine combined heat and power plant concept to meet the continuous total energy needs of a small community. J. Heat Recover. Syst. 1986, 6, 399-419. [CrossRef]

19. Cot, A.; Ametller, A.; Vall-Llovera, J.; Aguiló, J.; Arqué, J.M. Termosolar Borges: A thermosolar hybrid plant with biomass. In Proceedings of the Third International Symposium on Energy from Biomass and Waste, Venice, Italy, 8-11 November 2010; p. 5.

20. Gómez, A.; Rodrigues, M.; Montañés, C.; Dopazo, C.; Fueyo, N. The potential for electricity generation from crop and forestry residues in Spain. Biomass Bioenerg. 2010, 34, 703-719. [CrossRef]

21. García-Maraver, A.; Zamorano, M.; Ramos-Ridao, A.; Díaz, L.F. Analysis of olive grove residual biomass potential for electric and thermal energy generation in Andalusia (Spain). Renew. Sustain. Energy Rev. 2012, 16, 745-751. [CrossRef]

22. Junta de Andalucia. Aplicaciones energéticas de la biomasa en Andalucía. In La biomasa en Andalucía; Agencia Andaluza de la Energía: Isla de la Cartuja, Sevilla, 2017; pp. 25-35.

23. Pérez, Á.; Torres, N. Solar parabolic trough-biomass hybrid plants: A cost-efficient concept suitable for places in low irradiation conditions. In Proceedings of the SolarPACES Conference, Perpignan, France, 21-24 September 2010.

24. Peterseim, J.H.; White, S.; Hellwig, U.; Tadros, A.; Klostermann, F. Concentrating solar power/Energy from waste hybrid plants-Creating synergies. In Proceedings of the SolarPACES Conference, Marrakech, Morocco, 11-14 September 2012.

25. Fluri, W.; Lude, T.P.; Lam, S.; Morin, J.; Paul, G.; Platzer, C. Optimization of live steam properties for a linear Fresnel power plant. In Proceedings of the SolarPACES Conference, Marrakech, Morocco, 11-14 September 2012.

26. Peterseim, J.H.; Hellwig, U.; Tadros, A.; White, S. Hybridisation optimization of concentrating solar thermal and biomass power generation facilities. Sol. Energy 2014, 99, 203-214. [CrossRef]

27. Colmenar-Santos, A.; Bonilla-Gómez, J.-L.; Borge-Diez, D.; Castro-Gil, M. Hybridization of concentrated solar power plants with biogas production systems as an alternative to premiums: The case of Spain. Renew. Sustain. Energy Rev. 2015, 47, 186-197. [CrossRef]

28. Nagaraj, R.; Thirugnanamurthy, D.; Rajput, M.M.; Panigrahi, B.K. Techno-economic analysis of hybrid power system sizing applied to small desalination plants for sustainable operation. Int. J. Sustain. Built Environ. 2016, 5, 269-276. [CrossRef]

29. Khan, E.U.; Martin, A.R. Optimization of hybrid renewable energy polygeneration system with membrane distillation for rural households in Bangladesh. Energy 2015, 93, 1116-1127. [CrossRef]

30. Calise, F.; d'Accadia, M.D.; Piacentino, A.; Vicidomini, M. Thermoeconomic optimization of a renewable polygeneration system serving a small isolated community. Energies 2015, 8, 995-1024. [CrossRef]

31. Jhansi, S.; Mishra, S. Wastewater Treatment and Reuse: Sustainability Options. J. Sustain. Dev. 2013, 10, 1-15.

32. NYWEA and Syracuse University, Introduction to Wastewater Management. Handbook on Wastewater Management for Local Representatives; NYWEA: New York, NY, USA, 2015; pp. 1-18. 
33. American Water Works Association. Potable Reuse 101. An Innovative Sustainable Water Supply Solution; American Water Works Association: Denver, CO, USA, 2016.

34. Pisani, P.D.; Menge, J.G. Direct potable reclamation in Windhoek: A critical review of the design philosophy of new Goreangab drinking water reclamation plant. Water Sci. Technol. Water Supply 2013, 13, $214-226$. [CrossRef]

35. WateReuse; American Water Works Association; Water Environment Federation; NWRI. What is direct potable reuse. In Framework for Direct Potable Reuse; WateReuse Research Foundation: Alexandria, VA, USA, 2015; pp. 31-44.

36. Lahnsteiner, J.; van Rensburg, P.; Esterhuizen, J. Direct potable reuse-A feasible water management option. J. Water Reuse Desalin. 2018, 8, 14-28. [CrossRef]

37. Montoya, F.G.; Aguilera, M.J.; Manzano-Agugliaro, F. Renewable energy production in Spain: A review. Renew. Sustain. Energy Rev. 2014, 33, 509-531. [CrossRef]

38. Ruiz-Romero, S.; Colmenar-Santos, A.; Gil-Ortego, R.; Molina-Bonilla, A. Distributed generation: The definitive boost for renewable energy in Spain. Renew. Energy 2013, 53, 354-364. [CrossRef]

39. REE. Renewable Energy in the Spanish Electricity System (Las Energías Renovables en el Sistema Eléctrico Español); RED Electrica de España: Madrid, Spain, 2016.

40. Ministerio de energía, turismo y ageda digital. Overview of national energy efficiency targets and savings. In 2017-2020 National Energy Efficiency Action Plan; European Commission: Brussels, Belgium, 2017.

41. García-Vila, M.; Lorite, I.J.; Soriano, M.A.; Fereres, E. Management trends and responses to water scarcity in an irrigation scheme of Southern Spain. Agric. Water Manag. 2008, 95, 458-468. [CrossRef]

42. Real Decreto 1620/2007, de 7 de diciembre, de Régimen Jurídico de la Reutilización de las Aguas Depuradas. BOE, 8 de diciembre de 2007; Boletín Oficial del Estado: Madrid, Spain, 2007; pp. 50639-50661.

43. Iglesias, R.; Ortega, E.; Batanero, G.; Quintas, L. Water reuse in Spain: Data overview and costs estimation of suitable treatment trains. Desalination 2010, 263, 1-10. [CrossRef]

44. Bejan, A.; Tsatsaronis, G.; Moran, M.J. Thermal Design and Optimization; Wiley: New Jersey, NJ, USA, 1996.

45. Petela, R. Exergy of undiluted thermal radiation. Sol. Energy 2003, 74, 469-488. [CrossRef]

46. Towler, G.; Sinnott, R. Chemical Engineering Design Principles, Practice and Economics of Plant and Process Design Second Edition, 2nd ed.; Elsevier Ltd.: Amsterdam, The Netherlands, 2013.

47. Obi, M.; Jensen, S.M.; Ferris, J.B.; Bass, R.B. Calculation of levelized costs of electricity for various electrical energy storage systems. Renew. Sustain. Energy Rev. 2017, 67, 908-920. [CrossRef]

48. Marquardt, D.W. An Algorithm for Least-Squares Estimation of Nonlinear Parameters. J. Soc. Ind. Appl. Math. 1963, 11, 431-441. [CrossRef]

49. Williams, R., Jr. Six-Tenths Factor Aids in Approximating Costs. Chem. Eng. 1947, 54, 124-125.

50. Guo, T.; Englehardt, J.; Wu, T. Review of cost versus scale: Water and wastewater treatment and reuse processes. Water Sci. Technol. 2014, 69, 223-234. [CrossRef]

51. REE. Mercados Y Precios|Esios Electricidad Datos Transparencia. REE. Available online: https://www.esios. ree.es/es/mercados-y-precios (accessed on 4 November 2018).

52. Augsburger, G. Thermo-Economic Optimisation of Solar Tower Thermal Power Plants. Ph.D. Thesis, EPA, Switzerland, 2013; pp. 1-171.

53. ACC. Comparing disinfection methods. In Drinking Water Chlorination-A Review of US Disinfection Practices and Issues; Chlorine Chemistry Division: Washington, DC, USA, 2018; pp. 26-29.

54. Andersson, H.; Forss, M. Microbiological Risk Assessment of the Water Reclamation Plant in Windhoek, Namibia. Master's Thesis, Chalmers University of Technology, Gothenburg, Sweden, 2011; pp. 1-106.

55. Pisani, P.L.D. Direct Reclamation of Potable Water at Windhoek's Goreangab Reclamation Plant; Elsevier: Amsterdam, The Netherlands, 2005; pp. 14-17.

56. Menge, J. Treatment of Wastewater for Re-Use in the Drinking Water System of Windhoek; Water Institute of Southern Africa Conference: Midrand, Southern Africa, 2010.

57. IRENA. Renewable Energy Technologies Cost Analysis Series: Concentrating Solar Power. Compr. Renew. Energy 2012, 3, 595-636.

58. Wilson, N. 20 MW Gemasolar Plant: Elegant; However, Pricey; Energy Central; Available online: https: //www.energycentral.com/c/ec/20mw-gemasolar-plant-elegant-pricey (accessed on 4 November 2011). 
59. Wagner, S.J.; Rubin, E.S. Economic implications of thermal energy storage for concentrated solar thermal power. Renew. Energy 2014, 61, 81-95. [CrossRef]

60. OCU. Price of water in Spain. In Price of Water in 53 Citie. Available online: https://www.iagua.es/noticias/ espana/ocu/16/09/29/cuanto-cuesta-agua-ciudades-espanola (accessed on 4 November 2016).

(C) 2019 by the authors. Licensee MDPI, Basel, Switzerland. This article is an open access article distributed under the terms and conditions of the Creative Commons Attribution (CC BY) license (http://creativecommons.org/licenses/by/4.0/). 